\title{
Fossils, frogs, floating islands and expanding Earth in changing-radius cartography - A comment to a discussion on Journal of Biogeography
}

\author{
Giancarlo Scalera \\ Istituto Nazionale di Geofisica e Vulcanologia, Roma, Italy
}

\begin{abstract}
In this short note I have tried to make clear the issues surrounding a recent discussion on changing-radius paleobiogeographical problems of the Pacific Ocean biotic distribution. It is stressed that such an important discussion cannot be developed in the absence of proper cartographic methods that must necessarily introduce an increasing radius parameter, highlighting the effects of a changing curvature in the continental/oceanic plates in their movements from a globe of a given radius to a new position on a globe of different radius. Many other aspects of paleogeography, paleomagnetism, paleoclimate can be faced in a new and more open-mind philosophy and considered in a legitimate additional degree of freedom: globe size increasing. The new increasing-radius Cartography can become of fundamental importance for the advancement of science - not only of Earth sciences.
\end{abstract}

Key words changing radius cartography - paleogeography - biogeography - Pacific paleobiogeography - expanding Earth

\section{Introduction}

Recently a lively discussion was hosted by the Journal of Biogeography on the still unresolved problem of disjointed distribution of fossils on the opposite coasts of the Pacific (Scalera, 2001; McCarthy, 2003, 2005; Briggs, 2003, 2004, 2006; Ali, 2006). Briggs has once again been disappointed with the expanding Earth framework (Briggs, 2003, 2004) albeit he in a clear headed way recognizes that some problems concerning Indian Ocean Paleo-geog-

Mailing address: Dr. Giancarlo Scalera, Istituto Nazionale di Geofisica e Vulcanologia, Via di Vigna Murata 605, 00143 Roma, Italy; e-mail: scalera@ingv.it raphy deserve a different solution. The well documented fact that the Pacific Ocean - like the Atlantic Ocean - possesses a number of paleontologic correspondences among terrestrial and freshwater organisms characterised by a low propensity to long dispersal, must be considered an unresolved problem. It is also a paradox or an anomaly - in the Kuhnian (Kuhn, 1962) sense - both in plate tectonics and in general culture.

Many times since the work of Linnaeus the relationship between Eastern Asia and North America has been noted (Anonymous, 1984). Croizat (1961), the 20th century panbiogeographer, says that one should not forget geology and other environmental factors in biogeographical research. He was compelled to divide North America into two distinctive east and west biogeographical regions (Heads, 2005), which he interpreted as formerly physically separate - the western region being accreted to the eastern one by a single or multiple terrane collision. Allochtonous biotas rafted by these 

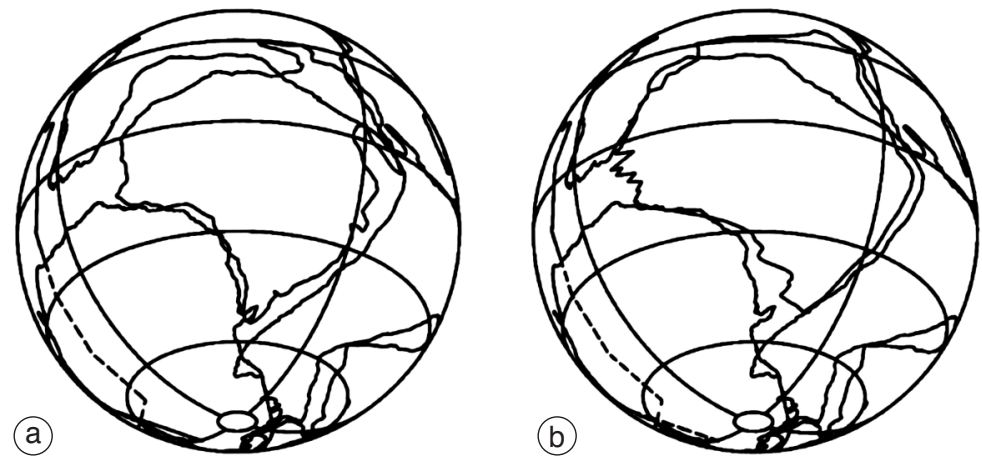

Fig. 1a,b. Two reconstructions of the Pacific side of Pangea on a globe of $3500 \mathrm{~km}$ radius. Continental scarps are represented. a) Australia east margin is in proximity with Western South America, and Western Laurentia is in proximity with Western and Northern Australia-New Guinea. b) The same occurs for the Nazca Plate, which did not exist in this epoch, but could be considered the actual track of the ancient position of Australia (see fig. 2a,b for a generalisation). The mutual position of Australia, South America, Laurentia, satisfies the necessity of paleontological links across the Pacific. It should be noted that albeit the adopted cartography is rigorous, the evolving increasing dimension of the continents is not taken into account in these reconstructions and they should be considered only indicative. Especially the extension of Asia is penalized in this map, and cutting younger Mesozoic and Cenozoic terrains could be closer to reality.

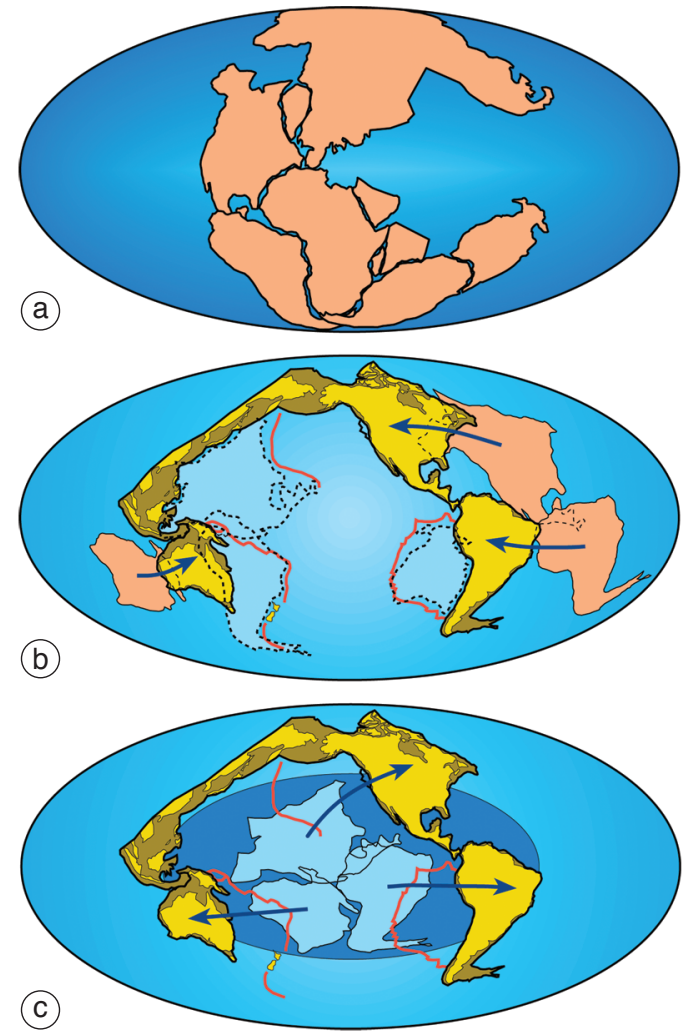

Fig. 2a-c. Shape conformities in the Pacific Hemisphere. a) The classical Pangea. b) Besides the classic similarities of shape observed between opposite coasts in the Atlantic, some conformities are observable in the Pacific periregion among continents and basins, e.g., between Laurentia and the North-Western Pacific Basin (bounded by trenches, north of New Guinea, Asian trenches and Emperor Hawaii volcanic chain), between Australia and Nazca basins and between South America and the Coral-Tasman Sea. It is truly impossible for these pairs of similarities to have been created if the paths of the continents have followed the arrows connecting in b) the Pangea positions of the continents and their Recent positions. The basin conformities of the continents are on the opposite side of the destination hemisphere. In c) it is easy to appreciate that if once the Earth was before Pangea break-up - smaller than the modern Earth, of approximately half the present radius, the displacements of the continents from Pangea (which covers all the planet) towards the modern positions are mostly radial (with rotations). The continents start from positions which are mere superimpositions and juxtapositions of all the conformities.

terranes was then introduced in North America, but an expanding Earth explanation appears more natural in fitting the facts. A number of subsidiary floristic trans-Pacific disjunctions 
(Heads, 2003) can be recalled besides a number of faunal ones (Scalera, 2001).

The description of the situation by Oakley Shields in 1993 and 1998 was highly opportune. Oakley stressed that the proximity of the now widely separated lands is required by a theory, the Vicariance hypothesis (or 'intervening natural barriers') model, which is independent of plate tectonic or other frameworks. The conclusions of Shields - which I share are in favour both of a real old land connexion between today's fossiliferous territories lacking continuity (Shields, 1983, 1991, 1996), and of a well grounded trust in an expanding Earth. The land connections are not, obviously, the equivalent of the land bridges that were a widespread concept before the advent of mobilism, but an initial proximity of the lands then separated by an intervening sea floor expansion such as the progressive opening of the Atlantic between Africa-Eurasia and the Americas.

The science of vicariance and cladistics has become a powerful method in tracking both the pathway and the evolution of the organisms on the continents (Humphries and Parenti, 1986). A vivid recent example is the case of the frogs in the Mediterranean region (Fromhage et al., 2004). In this case, too, the vicariance-cladistic method informs us that once - a few tens of million of years ago - Africa and Europe must have been closer to being unified. If not, Sicily which is an inseparable part of the African continental platform - must have split off from Africa, to become located together with Sardinia and Corsica near the western tip of the Alps. It then travelled like Noah's Arc toward its actual position (see figures in Fromhage et al., 2004). Clearly other solutions can be imagined, but considering other strong general evidence (see Carey, 1983; Scalera, 1993, 2003b, 2006a,b and figs. 1a,b and 2a-c), the more parsimonious hypothesis is the proximity of Africa to Europe, an opening of the Mediterranean (Scalera, 2005) and a global Earth's expansion. The entire concept of the closing of several Tethys seas (a closure caused by subduction and collision) should be reinterpreted, considering biogeographic subjects in the new light (Corbet, 1967) of a different origin of the paleontological separation between European and African biota. A belt of arid regions instead of interposed seaways can be a valid solution (fig. 3 ).

In addition, some Triassic fossils of primordial mammals, (Ambondro Mahabo, a small rodent; and teeth of Tribosfenidis, a group which includes most current mammals) have recently been found in Madagascar sediments (Flynn et al., 1999). These findings are judged surprising because they are located in the Southern Hemisphere, the Northern one long being supposed to be the region of origin of the tribosphenic mammals. Many other findings from South America North Africa and Australia (Flynn et al., 1999) are confirming the wider distribution of tribosphenic mammals and the conceptually untenable idea of a large Tethys Sea separating Laurasia and Gondwana (Chudinov, 1980; Stöklin, 1989; Scalera, 2005). These discoveries, besides the accumulating fossil evidence of Cretaceous Asian and Gondwanan mammals in India (Prasad and Lapparent de Broin, 2002; Rana and Wilson, 2003; among many others) support a position of Madagascar and India similar to that proposed in my Triassic reconstruction (Scalera, 2001), which allows a synthesis of all the constraints, avoiding the isolation of India on a too long northward trip and giving a sense to global constraints like those shown in fig. $2 \mathrm{a}-\mathrm{c}$ and to others like the socalled 'expanding ring' of Ilton Perin (1994, 2003) - a geographic greatcircle that does not cross subduction zones but only rifting regions and that constitutes a fundamental proof of a global expansion. All the same, an expanding Earth reconstruction of the Indian Ocean region can reconcile a number of problems such as that concerning the eutherian radiation (Archibald, 2003). Briggs' attempt to come out from paradoxes adopting the strategy 'to run with the hare and hunt with the hounds' - namely to enlarge Northern India and maintain it near Africa - is worthy of consideration and is a little ahead on preceding tries like the solution of Chatterjee (1992) but it lacks generality because the same elongation could be alleged for all the fragments (e.g., Cimmerian) which made rapid and nonsense trips from Africa to Eurasia, in perfect analogy with the alleged Indian trip - and the generality should extend to the Pacific Ocean with its disjointed 
Palaeontologic barrier on Africa and Eurasia

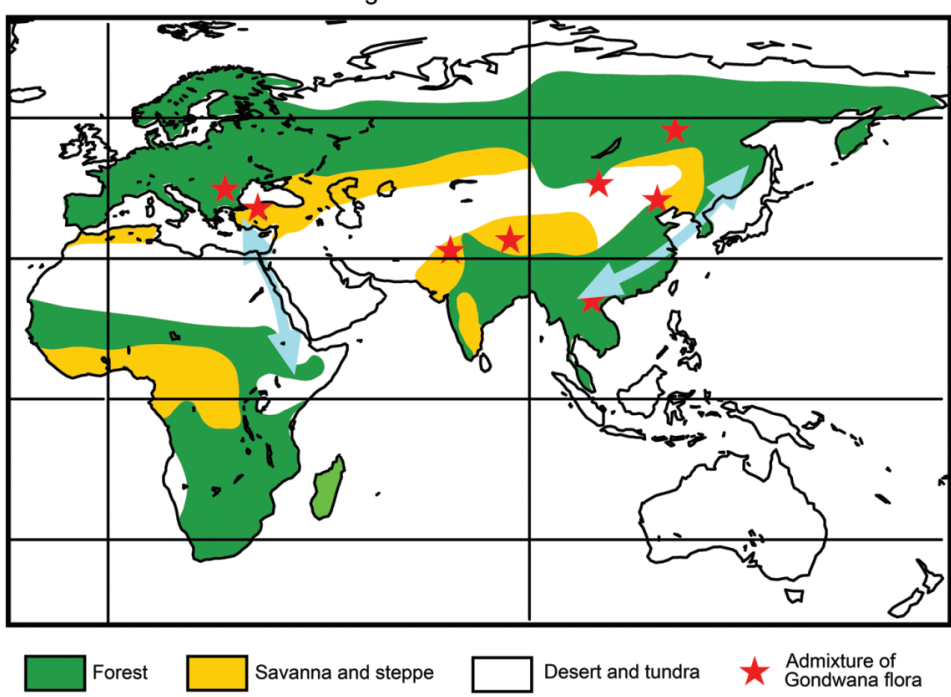

Fig. 3. The paleontologic separation of Laurasia from Gondwana is generally ascribed to the presence of a large interposed ocean, a time succession of Tethys seas. But frequent findings of Gondwanian fossils are present in Western Eurasia (red stars), which was the region of a wide Tethys Sea, and consequently of efficient paleontological separation. A different explanation of this can be the presence on the entire geologic time window of arid regions whose maximum expression is today called Sahara (Corbet, 1967). The oscillating presence of this desert has had the same function of paleobiogeographic separator, possessing on its longitudinal extension the same area (green zones and light blue double arrows) of easier communication and mixing between southern and northern floras on East Asia. The double arrows indicate the possible avenues of paleontological communications on East Asia along non-arid regions, and along Arabian and Anatolia regions following narrow waterways like the modern Red Sea that could have opened and closed in these regions through geologic time, as is witnessed by the Middle East ofiolitic belt (Stöklin, 1989, 1990). A complement to this hypothesis is a narrower Tethys in a still opening state - an opening slower but analogous to that of all the other oceans - that can more easily explain both the presence of Cadomian (Late Proterozoic to Early Cambrian) Gondwanian fragments in Eurasia and of Hercynian (Middle to Late Paleozoic) Eurasian fragments in North Africa.

Cathaysian flora. Among these problems, particularly astonishing and worth mentioning is the terrane distribution along Indochina and Sunda Arc (see fig. 1 in Shi and Archbold, 1998), which seems constituted by a perfect matching of relatively narrow slices with Gondwanan (W ans SW) and Cathaysian (E and NE) affinities - they would have had to travel on very special and finalized paths to form such a delicate and narrow arc. All these problems belong to the same class, are interrelated and cannot be dealt with as independent issues. The paleogeographic reconstruction of Briggs does not seem to directly use the geophysical constraints of paleopoles and of mag- netic anomalies of the Indian Ocean floor. Rana and Wilson (2003) enumerate five possible ways to overcome the paradoxes but they again do not explicitly consider the legitimate expanding Earth hypothesis among the set (for a more impartial account see Humphries and Parenti, 1986; Huggett, 2006).

More general and still outstanding interrelated problems can be seen in a new way on an expanding planet that shows the maximum rate of the asymmetrical expansion on the growing $\mathrm{Pa}-$ cific. In my paleogeographical reconstructions (Scalera, 2003b, 2006a), the region of maximum rate of expansion (fig. 5) migrates from north-west Pacific in the Jurassic, crossing the 
paleoequator at $50 \mathrm{Ma}$ ago, toward the current Nazca triple point, and producing the (hitherto unexplained in the plate tectonic geodynamic framework) reversal in direction of the True Polar Wander (TPW) path (Besse and Courtillot, 1991, 2002). A noteworthy unified explanation can be found for both the TPW (through geological time) and Polar motion (detected in the last 150 years) secular path, which instead have different (!) causes in the current paradigm (Scalera, 2006a). This migrating maximum expansion region, along whose path the uneven and volcanic crust of the Darwin rise was emplaced up to the Cretaceous, was almost certainly the site of a violent coastal ecological environment (frequent eruptions, earthquakes, tsunamis, uplifting or subsiding terranes, winds, orogenic processes etc.) of a relatively still narrow ocean that could have worked as an evolutionary force and forming in the flowering plants. The role of the Pacific as cradle of the angiosperm evolution was already proposed by Smith (1970) and some characteristics of the group show an optimal adaptation to the condition of the volcanic terranes and to their gaseous sulphuric emissions (Heads, 2003). Many others presented opinions on the necessity of extreme stressed environments in the history of angiosperm evolution (see exemples in the papers of Takhtajan and of Stebbins in the book edited by Beck; see Stebbins, 1976; Takhtajan, 1976) but their origin is still judged a great mystery (Crane et al., 1995; Frohlich and Chase, 2007). Earlier favouring causes of angiosperm origin can be envisaged in the influence of the same environment in its first stages in the evolution of insects and their wings.

Moreover, the same regional environmental pressure could have affected animals in their differentiation and in their evolving towards marsupials. The evolutive history (Cifelli and Davis, 2003, and quoted references) and early origin (Luo et al., 2003) of the Metatheria can be put in accord with the progressive southern migration of the more disturbed region of the enlarging Pacific. The evolutive advantage for a
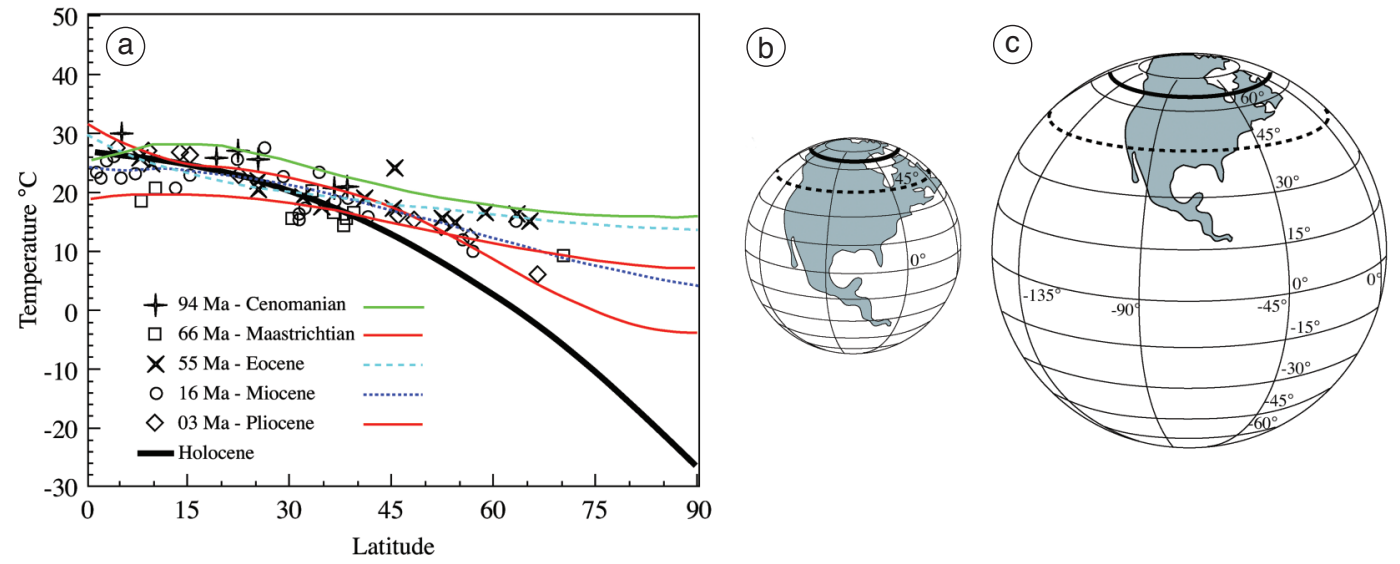

Fig. 4a-c. a) The latitudinal trend of temperature through geological time (modified by Crowley and Zachos, 2000). The distortion with respect to the modern curve is more and more marked going further back into older periods. The next two cartoons can help to understand a possible explanation in the expanding Earth framework. On a half radius Earth b), the polar circle encloses an area only a fourth of the modern area in c). As consequence the polar circle or a glaciation with ice reaching intermediate latitudes, $45^{\circ}$, occupy a lesser continental area $(1 / 4)$ on a half radius Earth. If people erroneously assume the radius of the Earth to be constant, the climate of the old epochs can be judged abnormally mild, presenting fossils of non-glacial flora and fauna enclosed in a modern size polar circle. The existence of warm and equable climate in the Meso-Cenozoic is an ongoing problem of paleoclimatology. 
Triassic -220 My $R=3300 \mathrm{~km}$
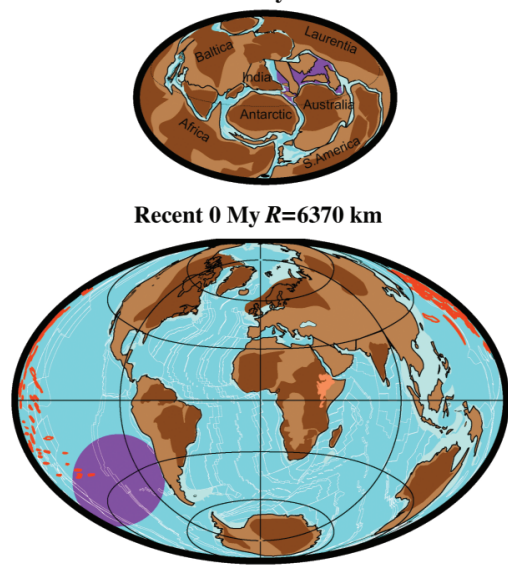

Future +250 My $R=9000 \mathrm{~km}$

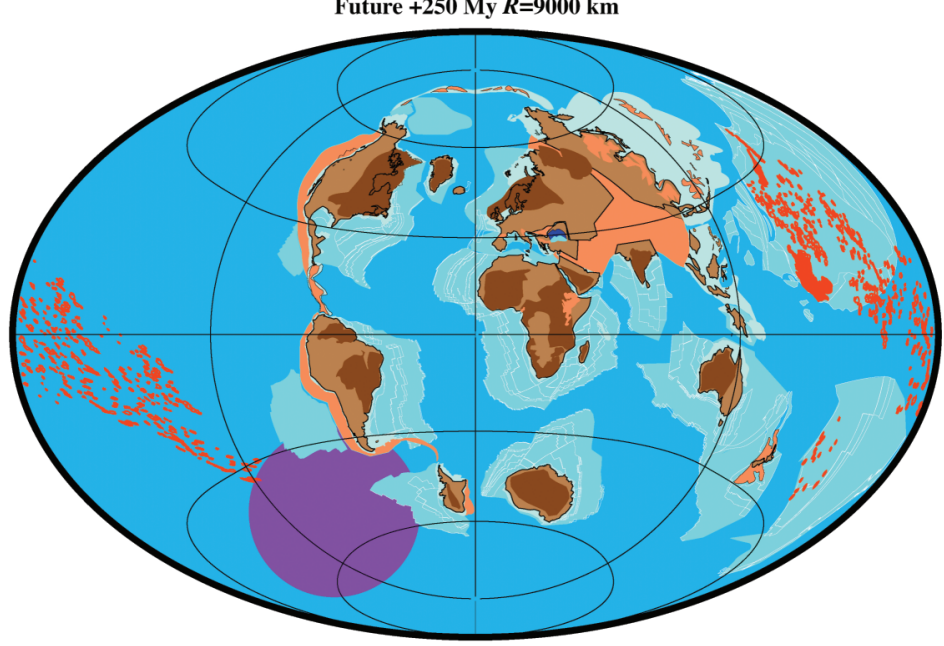

Fig. 5. In expanding-Earth Paleogeography, the evolution of the Mediterranean Sea has a more favourable projection into the future. This region, that plate tectonics claims is destined to complete closing, will continue to remain open and growing in the expanding-Earth view. The expansion rate of the Mediterranean is conceivably less than the opening rate of the other oceans because the Central Eurasian region is antipodal to the Pacific triple point, where the maximum expansion rate occurs. This region of maximum asymmetrical expansion (see the violet zones in this figure) migrates in the course of geologic time from the Northern Hemisphere to the Southern one leaving behind a track of sea-floor volcanoes and the Darwin Rise. This southward migration of the region of maximum expansion rate can explain the path of the True Polar Wander (TPW) and of the actual secular Polar Motion. The slowing down, stopping and reversing direction of the TPW path around $50 \mathrm{Ma}$ - the so called stasis (Besse and Courtillot, 2002) - can be easily explained through the laws of changing inertial moment of classical mechanics by the approach of the region of maximum spreading to the equator, to its crossing at $50 \mathrm{Ma}$ (the stasis period) and prosecution toward its actual position. The expansion of the Earth as represented here is only one version of a number of possibilities. On the contrary, the possibility of a complete phase transition of the liquid core materials towards the solid mantle mineralogical phases implies only, starting from the recent times, a further more moderate $20 \%$ of expansion. Waiting that the cause of the expansion is being sought, variable radius cartography can render wonderful mapping of the past and future for each of these possibilities, helping paleontologists to test a wider set of different paleogeographic reconstructions with greater freedom, whether on constant or variable size globes. 
pouch in which the mother can ever have the joey under her control could have had its origin in the frequent occurrence of violent geological events and fires with consequent necessity of rapid flights. Alternative interpretations and details can be provided, but this should be sufficient to show the new lines of thinking, from their starting point, opened by an asymmetrically expanding globe, which is more spherical then the one defended by Briggs.

However, what is still lacking in the discussion is clearly the dismissal of changing-radius cartography as a background for the discussion. While the use of precise cartographic methods is preferable but not required to the old-guard palaeontologists, it should be adopted by people - like Jason Ali and Dennis McCarthy who are willing to take part in a debate where maps are highly important, considering that some steps forward have been made since 1933 by Hilgenberg (1933) with careful transfer of the continental outlines among different size globes (Scalera and Braun, 2003), by Owen (1976, 1983a,b) with classical non-computerised methods and using specific software by Scalera $(1988,1990,1993)$. The effect of the decreasing radius and increasing curvature on the transfer of Pangea to a half radius Earth, is that the Pacific coasts of the continents can strongly change their azimuth direction. The Western North American margin rotates until assuming a near equatorial position and direction. This is at odds, cartographically, with the Oakley Shields paleogeographic model - a model similar to those of Mantovani (1909) (Scalera, 2003a) and Hughes (1975), which was still adopted by Carey in 1994 (Carey, 1994) but not at odds with his legitimate claim of the proximity of Laurentia to Asia and Australia (Shields, 1983, 1991, 1996), based on copious data. The Ali arguments are useless exercises using a wrong method against the same wrong cartographic method adopted by a young researcher, and does not confute the paleontological argument of transpacific links, nor of a planetary expansion. To be more exact, Ali cannot reject the McCarthy half-radius Pacific reconstruction because his counterarguments should be developed on a half radius planet (see the Pacific side of Pangea on a $3500 \mathrm{~km}$ radius globe in fig. 2a-c; Scalera, 1988). McCarthy ignores the Pangea configuration on the Pacific side of a half-radius globe because he does not handle the appropriate cartography.

To show only some examples of the advantages that variant-radius mapping can offer, besides the new perspectives in research it can introduce, see fig. 4a-c and fig. 5. These are elaborations and interpretations of paleoclimatological data and of the global paleo- and future ge-

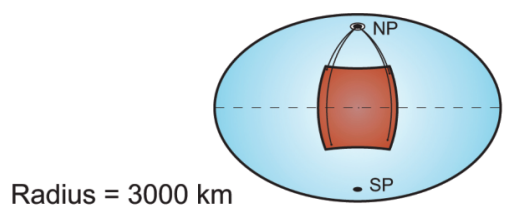

(a)

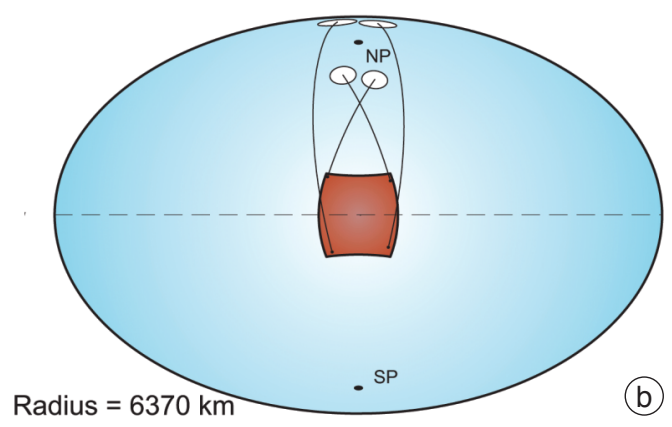

Fig. 6a,b. Transferring of both a plate and its sampled poles on a globe of greater radius. a) Four observers on the four corner of the plate must individuate the same magnetic pole using rock samples that formed in the observers age. b) If the globe increase its radius, four new observers, using samples of the rocks used by the older observers does not individuate a unique paleopole. The dispersion of the paleopoles is the result of the need for two different laws of transformation: the plate must conserve its area (but other choices are possible. E.g., conserve distances), while the poles must conserve their distance in degrees (with respect to Earth's center) from the sampling site. The figure has been drawn using cartographic software that takes into account the local deformation in the proximity of the sampling site. The first steps and considerations about the new properties of the paleopole distributions on an expanding globe were published by Egyed (1956a,b), Ward (1963), Hospers and Van Andel (1967), Van Andel (1968). 
ography. New solutions $-e . g$., the link between paleotemperatures and increasing radius and consequently new emerging problems such as the decoupling among the Pacific conformities of fig. $2 \mathrm{a}-\mathrm{c}-$ should be considered welcome in science. Additionally paleomagnetism could benefit from the the properties of dispersing the paleopoles on the sphere if the poles are plotted using a globe' radius different from that in existence at the epoch of the sample's primary magnetization (fig. 6a,b).

Cartography is the éminence grise of the Earth Sciences, and its rapid progress in the Renaissance went hand in hand with our evolving ideas on global tectonics. The first accurate maps of the continents provided the first clues that the continents moved relative to each other. The father of modern cartography, the geographer Abraham Ortelius (1527-1598), wrote a short statement on the fit of the Americas to Africa and Europe (Romm, 1994), and in 1620, in the Novum Organon, Francis Bacon (15611626) speculated about several kinds of analogies in the forms of the continents. The seeds of future mobilism were sown (Rupke, 1970; Goodacre, 1991; Romm, 1994; Scalera, 1999). Today, in the epoch of interactive digital facilities, we lack a popular cartographic tool allowing people to realize their cartographic and paleogeographic ideas with a legitimate additional degree of freedom: globe size variations. So be it, and let people judge the soundness of the results for themselves.

Planet Earth is the only planet on which orogenesis, mountain building and fold belts (which are not synonyms; see Ollier, 2003) and oceans occur, a fact that gives rise to consideration of the unique nature of our planet in the Solar system with such a large liquid core and such a large mantle and lithosphere. Could it be that a fluid core slowly changing phase (Egyed, 1960; Pickford, 2003) is linked to an expanding Earth, and that this expansion is the cause of a number of phenomena up to now explained so differently? Can cosmological causes (wimps, exotic particles, dark matter) produce a general celestial bodies expansion? Could deep earthquakes, volcanic arc, mid oceanic ridges, fold belts, trenches, secular polar motion, polhody, paleo-biogeography, and many other facts
(Scalera, 2007a,b, 2008) find a proper arrangement in this still open idea (still - luckily - not organized in a paradigm)? Can a planet in expansion favour the reconciliation of many sciences, in particular biology and geology? The answer to these questions is of fundamental importance for the advancement of science - not only Earth sciences.

Voltaire was ironic on the possibility that fossils on mountains could be the remains of meals of wayfarers. Is anyone today willing to propose that animals suddenly decided to swim across a large ocean? Or that frogs of the Alps - animals not liking salt water - passed running through France, Spain, Gibraltar, North Africa, to reach Sicily (or through the Apennines) without leaving progenies of fossils along their path? If so, we should ask these people why? And the debate could move on philosophically.

The modern situation is similar to the historical period of the discussions on the flat Earth against the spherical Earth. I hope to have shown in this short note that a new special spherical Earth, richer in still unappreciated properties, is waiting for the scientific community. These new properties, besides much new factual evidence as advocated by Briggs - should be disseminated in schools and universities.

\section{REFERENCES}

ALI, J.R. (2006): Biogeographical and geological evidence for a smaller, completely-enclosed Pacific Basin in the Late Cretaceous: a comment, J. Biogeogr., 33, 1670-1674.

ANONYMOUS (Editor) (1984): Biogeographical Relationships between Temperate Eastern Asia and Temperate Eastern North America (Missuori Botanical Garden, St. Louis), pp. 329.

ARChiBALD, J.D. (2003): Timing and biogeography of the eutherian radiation: fossils and molecules compared, Mol. Phylogen. Evol., 28, 350-359.

BECK, C.B. (Editor) (1976): Origin and Early Evolution of Angiosperms, Selected Contribution from the 1st International Congress of Systematic and Evolutionary Biology, held in Boulder CO August 1973 (Columbia University Press), pp. 341.

Besse, J. and V. Courtillot (1991): Revised and synthetic apparent polar wander paths of the African, Eurasian, North American and Indian plates, and true polar wander since $200 \mathrm{Ma}$, J. Geophys. Res., 96, 4029-4050.

Besse, J. and V. Courtillot (2002): Apparent and true polar wander and the geometry of the geomagnetic field over the last $200 \mathrm{Myr}$, J. Geophys. Res., 107 (B11), 2300, doi:10.1029/2000JB000050. 
BRIGGS, J.C. (2003): The biogeographic and tectonic history of India, J. Biogeogr., 30 (3), 381-388.

BRIGGS, J.C. (2004): The ultimate expanding Earth hypothesis. Correspondence, J. Biogeogr., 31, 855-857.

BRigGs, J.C. (2006): Another expanding Earth paper. Correspondence, J. Biogeogr., 33, 1674-1676.

CAREY, S.W. (Editor) (1983): The Expanding Earth - A Symposium, Earth Resource Foundation, Sydney, February 10-14, 1981, University of Tasmania (Impact Printing Ltd., Brunswick), pp. 423.

CAREY, S.W. (1994): Creeds of physics, in Frontiers of Fundamental Physics, edited by M. BARONE and F. SELlERI (Plenum Press, New York), 241-255.

ChatTerJeE, V.S. (1992): A kinematic model for the evolution of the Indian plate since the Late Jurassic, in New Concepts in Global Tectonics, edited by V.S. CHATTERJEE and N. HotTon III (Texas Tech University Press, Lubbock), 13-21.

Chudinov, Yu.V. (1980): Origin of the Alpine folding belt from the viewpoint of the expanding Earth hypothesis, in Tectonics of the Mediterranean Belt, edited by M.V. Muratov and A.L. Yanshin (Nauka Publ., Moscow), 223-237 (in Russian).

Cifelli, R.L. and B.M. Davis (2003): Marsupial origins, Science, 302, 1899-1900.

Corbet, G.B. (1967): The influence of Tethys on the pattern of distribution of recent mammals, in Aspect of Tethyan Biogeography, edited by C.G. ADAMS and D.V. Ager, Systematic Association Publ. No. 7 (London), 325-334.

Crane, P.R., E.M. Friss and K.R. Pedersen (1995): The origin and early diversification of angiosperm, Nature, 374, 27-33.

Croizat, L. (1961): Principia Botanica (published by the Author, Caracas), pp. 1821.

CRowley, T.J. and J.C. Zachos (2000): Comparison of zonal temperature profiles for past warm time periods, in Warm Climates in Earth History, edited by B.T. HuBER, K.G. MACLEOD and S.L. WING (Cambridge University Press, Cambridge), 50-76.

EGYED, L. (1956a): Determination of changes in the dimensions of the Earth from palaeogeographical data, $\mathrm{Na}$ ture, 178, 534-534.

EgYeD, L. (1956b): The change in Earth's dimensions determined from palaeogeographical data, Geofis. Pura Appl., 33, 42-48.

EGYED, L. (1960): On the origin and constitution of the upper part of the Earth's mantle, Geol. Rundschau, 50, 251-258.

Flynn, J.J., J.M. PARrish, B. RaKotosaminimanana, W.F. SimPSON and A.R. Wyss (1999): A Middle Jurassic mammal from Madagascar, Nature, 401, 57-60.

Frohlich, M.W. and M.W. Chase (2007): After a dozen years of progress the origin of angiosperms is still a great mystery, Nature, 450 (20), 1184-1189.

Fromhage, L., M. Vences and M. Veitha (2004): Testing alternative vicariance scenarios in Western Mediterranean discoglossid frogs, Mol. Phylogen. Evol., 31, 308-322.

GoodacRE, A. (1991): Continental drift, Nature, 354, 261261.

Heads, M. (2003): Ericaceae in Malesia: vicariance biogeography, terrane tectonics and ecology, Telopea, 10 (1), 311-449.
HEADS, M. (2005): Toward a panbiogeography of the seas, Biol. J. Linnean Soc., 84, 675-723.

HilgenberG, O.C. (1933): Vom wachsenden Erdball (The Expanding Earth), (Berlin, Giessmann \& Bartsch), pp. 56 (in German).

Hospers, J. and S.I. VAN Andel (1967): Palaeomagnetism and the hypothesis of an expanding Earth, Tectonophysics, 5 (1), 5-24.

HugGETT, R.J. (2006): The Natural History of the Earth. Debating Long-term Change in the Geosphere and Biosphere (Routledge, London and New York), pp. 203.

Hughes, T. (1975): The case for creation of the North Pacific Ocean during the Mesozoic Era, Palaeogeogr. Palaeoclimatol. Palaeoecol., 18, 1-43.

Humphries, C. and L.R. PARENTI (1986): Cladistic Biogeography (Clarendon Press, Oxford), ch. 4, pp. 98.

Kunn, T. (1962): The Structure of Scientific Revolutions (Univ. Chicago Pr., Chicago), 1st ed., pp. 168.

LuO, Z.-X., Q. JI, J.R. Wible and C.X. YuAN (2003): An early Cretaceous tribosphenic mammal and Metatherian evolution, Science, 302, 1934-1940.

Mantovani, R. (1909): L'Antarctide, Je m'Instruis, la Science pour Tous, 38, 595-597.

MCCARTHY, D. (2003): The trans-Pacific zipper effect: disjunct sister taxa and matching geological outlines that link the Pacific margins, J. Biogeogr., 30, 1545-1561.

MCCARTHY, D. (2005): Biogeographical and geological evidence for a smaller, completely-enclosed Pacific Basin in the Late Cretaceous, J. Biogeogr., 32, 2161-2177.

OLLIER, C.D. (2003): The origin of mountains on an expanding Earth, and other hypotheses, in 'Why Expanding Earth? - A book in Honour of Ott Christoph Hilgenberg', Proceedings of the 3rd Lautenthaler Montanistisches Colloquium, Mining Industry Museum, Lautenthal (Germany), May 26, 2001, edited by G. SCALERA and K.-H. JACOB (INGV, Roma), 129-160.

OwEN, H.G. (1976): Continental displacements and expansion of the Earth during the Mesozoic and Cenozoic, Philos. Trans. R. Soc. London, Ser. A, 281 (1303), 223-291.

Owen, H.G. (1983a): Some principles of Physical Palaeogeography, in Evolution, Time and Space, the Emergence of the Biosphere, edited by R.W. SIMS, J.H. PRICE and P.E.S. WALLEY, Systematic Association Spec. Vol. No. 23 (Academic Press, London and New York), 85-114.

Owen, H.G. (1983b): Atlas of Continental Displacement, 200 Million Years to the Present (Cambridge University Press, Cambridge), pp. 159.

PERIN, I. (1994): Expansão em anel hemisférico terrestre, Bol. Res. Expand. Soc. Bras. Geol., 2, 267.

PERIN, I. (2003): The expanding hemispheric ring, in 'Why Expanding Earth?-A book in Honour of Ott Christoph Hilgenberg', Proceedings of the 3rd Lautenthaler Montanistisches Colloquium, Mining Industry Museum, Lautenthal (Germany), May 26, 2001, edited by G. SCALERA and K.-H. JACOB (INGV, Roma), 243-257.

PICKFORD, M. (2003): The expanding Earth hypothesis: a challenge to plate tectonics, in 'Why Expanding Earth?- A book in Honour of Ott Christoph Hilgenberg', Proceedings of the 3rd Lautenthaler Montanistisches Colloquium, Mining Industry Museum, Lautenthal (Germany), May 26, 2001, edited by G. SCALERA and K.-H. JACOB (INGV, Roma), 233-242. 
Prasad, G.V.R. and F. LAPPARENT DE BROIN (2002): Late Cretaceous crocodile remains from Naskal (India): comparisons and biogeographic affinities, Ann. Paléontol., 88, 19-71.

RANA, R.S. and G.P. WILSON (2003): New Late Cretaceous mammals from the Intertrappean beds of Rangapur, India and paleobiogeographic framework, Acta Palaeontol. Pol., 48 (3), 331-348.

Romm, J. (1994): A new forerunner for continental drift, Nature, 367, 407-408.

RuPKE, N.A. (1970): Continental drift before 1900, Nature, 227, 349-350.

SCAlERA, G. (1988): Nonconventional Pangea reconstructions: new evidence for an expanding Earth, in The Origin and Evolution of Arcs, edited by F.-C. WEZEL, Tectonophysics, 146, 365-383.

SCALERA, G. (1990): Palaeopoles on an expanding Earth: a comparison between synthetic and real data sets, Phys. Earth Planet. Inter., 62, 126-140.

SCALERA, G. (1993): Non-chaotic emplacements of trench-arc zones in the Pacific Hemisphere, Ann. Geofis., XXXVI (5-6), 47-53.

SCAlera, G. (1999): I Moti e la Forma della Terra (The Motions and the Shape of the Earth), (Tangram-Istituto Nazionale di Geofisica, Roma), pp. 195.

ScAlERA, G. (2001): The Global paleogeographical reconstruction of the Triassic in the Earth's dilatation framework and the paleoposition of India, Ann. Geofis., 44 (1), 13-32.

SCAlERA, G. (2003a): Roberto Mantovani an Italian defender of the continental drift and planetary expansion, in 'Why Expanding Earth?- A book in Honour of Ott Christoph Hilgenberg', Proceedings of the 3rd Lautenthaler Montanistisches Colloquium, Mining Industry Museum, Lautenthal (Germany), May 26, 2001, edited by G. SCALERA and K.-H. JACOB (INGV, Roma), 71-74.

SCALERA, G. (2003b): The expanding Earth: a sound idea for the new millennium, in 'Why Expanding Earth?-A book in Honour of Ott Christoph Hilgenberg', Proceedings of the 3rd Lautenthaler Montanistisches Colloquium, Mining Industry Museum, Lautenthal (Germany), May 26, 2001, edited by G. SCALERA and K.-H. JACOB (INGV, Roma), 181-232.

SCAlERA, G. (2005): A new interpretation of the Mediterranean arcs: mantle wedge intrusion instead of subduction, Boll. Soc. Geol. Ital., 5 (Spec. Issue), 129-147.

SCALERA, G. (2006a): TPW and polar motion as due to an asymmetrical Earth expansion, in Frontiers in Earth Sciences: New Ideas and Interpretations, edited by G. LAVECCHIA and G. ScAlera, Ann. Geophysics, 49 (Suppl. to n. 1), 483-500.

SCALERA, G. (2006b): The geodynamic meaning of the deep earthquakes: first clues for a global perspective for fold belts?, New Concepts in Global Tectonics Newsletter, 41 (December), 45-54.

SCALERA, G. (2007a): Geodynamics of Wadati-Benioff zone earthquakes: the 2004 Sumatra earthquake and other great earthquakes, Geofís. Inter., 46 (1), 19-50.

SCALERA, G. (2007b): A new model of orogenic evolution, Rend. Soc. Geol. It., Nuova Ser., 5 (2007), 214-218.

ScAlerA, G. (2008): Great and Old Earthquakes against Great and Old Paradigms - paradoxes, historical roots, alternative answers. Proceedings of the 2nd Alexander von Humboldt International Conference on the Role of Geophysics in Natural Disaster Prevention, 5-9 March 2007, Lima, Peru, Adv. Geosci., 14 (1), 41-57.

Scalera, G. and T. Braun (2003): Ott Christoph Hilgenberg in twentieth-century Geophysics, in 'Why Expanding Earth? - A book in Honour of Ott Christoph Hilgenberg', Proceedings of the 3rd Lautenthaler Montanistisches Colloquium, Mining Industry Museum, Lautenthal (Germany) May 26, 2001, edited by G. ScAlERA and K.-H. JACOB (INGV, Roma), 25-41.

ShI, G.R. and N.W. ARCHBOLd (1998): Permian marine biogeography of SE Asia, in Biogeography and Geological evolution of SE Asia, edited by R. HALL and J.D. HollowaY (Backhuys Publisher, Leiden, The Netherlands), 57-72.

SHIELDS, O. (1983): Trans-Pacific Biotic Links that Suggest Earth Expansion, in Expanding Earth Symposium, University of Tasmania, Sydney 1981 (Impact Printing Ltd. Brunswick), 199-205.

SHIELDS, O. (1991): Pacific biogeography and rapid Earth expansion, J. Biogeogr., 18 (5), 583-585.

SHIELDS, O. (1996): Geological significance of land organisms that crossed over the Eastern Tethys 'Barrier' during the Permo-Triassic, Paleobotanist, 43 (3), 85-95.

ShieldS, O. (1998): Upper Triassic Pacific vicariance as a test of geological theories, J. Biogeogr., 25, 203-211.

Smith, A.C. (1970): The Pacific as a Key to Flowering Plant History (with a biographical sketch of Harold L. Lyon by H. St. John), University of Hawaii, Harold L. Lyon Arboretum Lecture Number One, Honolulu, pp. iv-28.

StebBINS, G.L. (1976): Seeds, seedlings, and the origin of Angiosperms, in Origin and Early Evolution of Angiosperms, selected contribution from the 1st International Congress of Systematic and Evolutionary Biology, held in Boulder CO August 1973, edited by C.B. BECK (Columbia University Press), 207-219.

STÖCKLIN, J. (1989): Tethys evolution in the AfghanistanPamir-Pakistan region, in Tectonic evolution of the Tethyan region, edited by A.M.C. SENGÖR (Kluwer Academic Publishers), 241-264.

STÖCKLIN, J. (1990): The coloured Melange of the Makran: A product of diapirism?, in Proceedings of the Symposium on Diapirism with special reference to Iran, 8-14 December 1990, Tehran, Iran (Geological Survey of Iran, Tehran University Press), 381-399.

TAKHTAJAN, A. (1976): Neoteny and the origin of flowering plants, in Origin and Early Evolution of Angiosperms, selected contribution from the 1st International Congress of Systematic and Evolutionary Biology, held in Boulder CO August 1973, edited by C.B. BECK (Columbia University Press), 207-219.

VAN ANDEL, S.I. (1968): A test of Earth expansion hypotheses by means of palaeomagnetic data, Ph.D. Thesis (Amsterdam University), pp. 103.

WARD, M.A. (1963): On detecting changes in the Earth's radius, Geophys. J.R. Astron. Soc., 8 (2), 217-225.

(received October 2, 2007; accepted March 14, 2008) 